\title{
Assessment Studies on Genetic Variability Traits in Different Lines of Tomato (Solanum lycopersicum L.)
}

\author{
Bandan Thapa $^{1^{*}}$, K. Srivastava ${ }^{2}$ and Hemraj Bhandari ${ }^{3}$ \\ ${ }^{1}$ Department of Genetics and Plant Breeding, Uttar Banga Krishi Viswavidyalaya, Regional \\ Research Station, Hill Zone, Kalimpong, West Bengal, India \\ ${ }^{2}$ Institute of Agricultural Sciences, Banaras Hindu University, Varanasi, Uttar Pradesh, India \\ ${ }^{3}$ Central Research Institute on Jute and Allied Fibres, Barrackpore, India \\ *Corresponding author
}

\section{A B S T R A C T}

\section{Keywords \\ Variability, Heritability, Genetic advance and Inheritance \\ Article Info \\ Accepted: \\ 06 August 2018 \\ Available Online: \\ 10 September 2018}

Thirty eight genotypes of tomato were evaluated for yield and yield-contributing characters. Various genetic parameters like variability, heritability and genetic advance were calculated. The test genotypes exhibited a wide range of variability for traits under consideration. These traits were also found to be highly heritable. Phenotypic coefficient of variation (PCV) was found to be greater than genotypic coefficient of variation (GCV) for all the characters studied. High heritability was observed for fruit yield plant ${ }^{-1}$ followed by average fruit weight while number of primary branches plant ${ }^{-1}$ exhibited lowest heritability results. High heritability combined with high genetic advance was shown by average fruit weight suggesting, additive gene action plays a major role in governing these traits. Thus, these traits are amenable to simple selection for their improvement.

\section{Introduction}

Tomato (Solanum lycopersicum L.) is an important vegetable crop grown throughout the world. Botanically, tomato is a diploid with somatic chromosome number $24(2 n)$ belonging to family Solanaceae, the nightshade family of common vegetables, which also includes chilli, peppers, potato, etc. Tomato ranks third in priority after Potato and Onion in India but ranks second after potato in the world. India ranks second in the area as well as in production of tomato after China (FAOSTAT, 2013). It has become more popular all over the world because of a good source of vitamins A and C, solids content, good taste and fruit set even at high temperature. It's direct use as raw vegetable to prepare in curries, stews, salads, fresh tomato juices as well as its soups and to make chutney have made it very popular (Bose et al., 2002). Tomato fruit provides 3-4\% sugar and total soluble solid in tomato ranges from 4 to $7 \%$. It contains $15-30 \mathrm{mg} / 100 \mathrm{~g}$ ascorbic acid, 7.5-10 $\mathrm{mg} / 100 \mathrm{~mL}$ titrable acids, $20-50 \mathrm{mg} / 100 \mathrm{~g}$ lycopene per fruit weight (Handbook of Horticulture, 2009). In addition, tomato has become a popular vegetable on account of its short duration, high yield potential, high profitability and economic viability (Bhandari 
et al., 2017). Its fruits are consumed more as a fruit rather than as a vegetable. Tomato is a premier vegetable crop of round the year and but the production and productivity of this crop in India is far below as compared to global scenario. Considering the potentiality of this crop, there is a need for improvement and to develop varieties suited to specific agro-ecological conditions and also for specific end use. Efforts are being made to increase its productivity and quality by developing improved varieties. A thorough knowledge regarding the amount of genetic variability existing for various characters is essential for initiating the crop improvement programme. With limited variability much cannot be achieved and the breeder will have to enrich the germplasm or resort to create greater variability through hybridization, mutation and polyploidy breeding.

Germplasm is a prerequisite for any breeding programme; serves as a valuable source material as it provides scope for building of genetic variability. Progress in any breeding programme depends upon the magnitude of useful variability present in the population and the extent to which the desirable characters are heritable. Study of variability, heritability and genetic advance in the germplasm will help to ascertain the real potential value of the genotypes. Lack of variability has been thought to be one of the important reasons for the slow progress witnessed in making any significant gains by crop breeding. Though there is considerable variability in the crop, much of it may be in the form of conserved variability in view of their autogamous nature providing little scope for the shuffling of genes. The study and utilization of existing variability becomes highly essential.

\section{Materials and Methods}

The present investigation was carried out during rabi season of 2012-2013 at Vegetable
Research Farm, Institute of Agricultural Sciences, Banaras Hindu University, Varanasi (UP), India. The experimental material consist of 38 genotypes / cultivars (both exotic lines and indigenous lines) of tomato received from various sources, including Indian Institute of Vegetable Research, Varanasi and National Bureau of Plant Genetic Resources, New Delhi, at Department of Genetics and Plant Breeding, Institute of Agricultural Sciences, Banaras Hindu University given in Table 1. The experiment was laid out in randomized block design with three replications. Nursery was planted in second week of August and about 4 week old seedlings were transplanted during second week of September with rowto-row x plant-to-plant spacing maintained at $60 \mathrm{~cm} \times 45 \mathrm{~cm}$. Each plot consists of 10 plants and represents a single entry in each replication. Standard agronomic practices were followed to raise a good crop. Observations on days to first flowering and days to $50 \%$ fruiting were taken on plot basis. Five plants, excluding border plants, were randomly selected for recording of data on various yield traits such as primary branches, secondary branches, plant height $(\mathrm{cm})$, clusters plant $^{-1}$, fruitscluster ${ }^{-1}$, fruit plant $^{-1}$, locule number, fruit shape index, pericarp thickness $(\mathrm{mm})$, average fruit weight $(\mathrm{g})$, fruit yieldplant $^{-1} \quad(\mathrm{~kg})$. Analysis of variance, genotypic coefficient of variation (GCV), phenotypic coefficient of variation (PCV), heritability (broad sense), genetic advance (GA), genetic advance as per cent of mean, was done using Windostat ${ }^{\circledR}$ ver. 8.5 software for statistical data analysis.

\section{Results and Discussion}

The extent of variability with respect to thirteen quantitative characters in thirty-eight germplasm measured in term of phenotypic coefficient of variation (PCV), genotypic coefficient of variation (GCV), heritability, genetic advance and genetic advance as 
percent of mean are given in Table 3. Analysis of variance revealed significant differences among germplasm for all the traits studies indicating presence of significant variability in the materials which can be exploited through selection Table 2. Similar results were noticed by Basavaraj et al., (2010), Singh and Cheema (2005), Kaushik et al., (2011), Dar and
Sharma (2011), Patel et al., (2013). The research was carried out with the aim to develop high yielding varieties than the existing ones. The available genetic variability in the gene pool provides the opportunity for selecting superior types. The identification of the potential parents is pre-requisite for taking up an efficient breeding programme.

\begin{tabular}{|c|c|c|}
\hline S. No. & Genotypes / Cultivars & Source \\
\hline 1. & PusaSadabahar & IARI, New Delhi \\
\hline 2. & DVRT-1-2 & IIVR, Varanasi \\
\hline 3. & H-88-7-4 & IIVR, Varanasi \\
\hline 4. & Floradale & IIVR, Varanasi \\
\hline 5. & DT-2 & IIVR, Varanasi \\
\hline 6. & $\mathrm{H}-24$ & IIVR, Varanasi \\
\hline 7. & NDT - 3 & NDUAT, Faizabad \\
\hline 8. & VR - 20 & IIVR, Varanasi \\
\hline 9. & HT - 4 & IIVR, Varanasi \\
\hline 10. & SwarnaLalima & IIVR, Varanasi \\
\hline 11. & TLC - 1 & IIVR, Varanasi \\
\hline 12. & GT-20 & IIVR, Varanasi \\
\hline 13. & FLA - 7171 & IIVR, Varanasi \\
\hline 14. & NDTVR - 60 & NDUAT, Faizabad \\
\hline 15. & Flawery & IIVR, Varanasi \\
\hline 16. & Feb - 04 & IIVR, Varanasi \\
\hline 17. & BT - 120 & IIVR, Varanasi \\
\hline 18. & $N F-315$ & IIVR, Varanasi \\
\hline 19. & PS - 1 & IIVR, Varanasi \\
\hline 20. & Columbia & IIVR, Varanasi \\
\hline 21. & Cholnak - k & IIVR, Varanasi \\
\hline 22. & T Local & IIVR, Varanasi \\
\hline 23. & EC - 521069 & NBPGR, New Delhi \\
\hline 24. & EC-521086 & NBPGR, New Delhi \\
\hline 25. & EC-521087 & NBPGR, New Delhi \\
\hline 26. & EC-528374 & NBPGR, New Delhi \\
\hline 27. & EC-531803 & NBPGR, New Delhi \\
\hline 28. & B-S-18-7 & IIVR, Varanasi \\
\hline 29. & B-S-2-5 & IIVR, Varanasi \\
\hline 30. & B-S-31-3 & IIVR, Varanasi \\
\hline 31. & B-S-24-2 & IIVR, Varanasi \\
\hline 32. & EC-520061 & IIVR, Varanasi \\
\hline 33. & EC -538434 & IIVR, Varanasi \\
\hline 34. & EC -538440 & IIVR, Varanasi \\
\hline 35. & EC -538405 & IIVR, Varanasi \\
\hline 36. & EC -539450 & IIVR, Varanasi \\
\hline 37. & EC -538156 & IIVR, Varanasi \\
\hline 38. & EC -538155 & IIVR, Varanasi \\
\hline
\end{tabular}




\begin{tabular}{|l|l|l|l|l|}
\hline \multicolumn{4}{|l|}{ Table.2 Analysis of variance for yield traits in 38 genotypes of tomato } \\
\hline S. No. & Characters & Mean Sum of Squares & \\
\hline & & Replication & Treatment & Error \\
\hline $\mathbf{1}$ & Days to first flowering & $14.798^{*}$ & $86.404^{* *}$ & 3.069 \\
\hline $\mathbf{2}$ & Days to 50 per cent fruiting & 6.342 & $71.598^{* *}$ & 2.937 \\
\hline $\mathbf{3}$ & Primary branches per plant & $4.312^{* *}$ & $1.401^{* *}$ & 0.292 \\
\hline $\mathbf{4}$ & Secondary branches per plant & $2.168^{*}$ & $17.835^{* *}$ & 0.657 \\
\hline $\mathbf{5}$ & Plant height & $239.092^{* *}$ & $633.236^{* *}$ & 36.496 \\
\hline $\mathbf{6}$ & Number of clusters per plant & 0.699 & $3.947^{* *}$ & 0.358 \\
\hline $\mathbf{7}$ & Number of fruits per cluster & 0.489 & $1.273^{* *}$ & 0.162 \\
\hline $\mathbf{8}$ & Number of fruits per plant & 10.87 & $707.255^{* *}$ & 7.742 \\
\hline $\mathbf{9}$ & Pericarp thickness & $0.038^{* *}$ & $0.024^{* *}$ & 0.004 \\
\hline $\mathbf{1 0}$ & Number of locules per fruit & 0.24 & $2.382^{* *}$ & 0.33 \\
\hline $\mathbf{1 1}$ & Average fruit weight & 26.289 & $936.063^{* *}$ & 19.037 \\
\hline $\mathbf{1 2}$ & Fruit yield per plant & 0.017 & $4.792^{* *}$ & 0.035 \\
\hline $\mathbf{1 3}$ & Fruit shape index & $0.036^{*}$ & $0.104^{* *}$ & 0.009 \\
\hline
\end{tabular}

Table. 3 Estimates of variability parameters for $\mathbf{1 3}$ yield attributes in tomato

\begin{tabular}{|c|c|c|c|c|c|c|}
\hline $\begin{array}{l}\text { S. } \\
\text { No }\end{array}$ & Traits/Parameters & PCV & GCV & $h^{2}(\mathrm{BS})$ & $\begin{array}{l}\text { GA } \\
(5 \%)\end{array}$ & $\begin{array}{l}\text { GA as \% of } \\
\text { Mean 5\% }\end{array}$ \\
\hline 1. & DFF & 14.15 & 13.43 & 90.10 & 10.30 & 26.25 \\
\hline 2. & D50Fr & 8.50 & 8.00 & 88.60 & 9.28 & 15.51 \\
\hline 3. & PB & 21.82 & 16.31 & 55.90 & 0.94 & 25.12 \\
\hline 4. & SB & 37.61 & 35.62 & 89.70 & 4.67 & 69.50 \\
\hline 5. & PH & 20.01 & 18.40 & 84.50 & 26.71 & 34.83 \\
\hline 6. & $\mathrm{Cl} / \mathrm{P}$ & 24.03 & 21.08 & 76.90 & 1.98 & 38.09 \\
\hline 7. & $\mathrm{Fr} / \mathrm{Cl}$ & 20.16 & 16.81 & 69.60 & 1.05 & 28.89 \\
\hline 8. & $\mathbf{F r} / \mathbf{P}$ & 32.61 & 32.08 & 96.80 & 30.95 & 65.01 \\
\hline 9. & PT & 21.41 & 16.61 & 60.20 & 0.13 & 26.54 \\
\hline 10. & LN & 28.00 & 23.00 & 67.50 & 1.40 & 38.92 \\
\hline 11. & FSI & 22.46 & 19.78 & 77.58 & 0.323 & 35.88 \\
\hline 12. & AFW & 45.44 & 44.09 & 94.10 & 34.94 & 88.12 \\
\hline 13. & FY/ P & 52.27 & 51.71 & 97.80 & 2.57 & 105.36 \\
\hline
\end{tabular}

A wide range and significant variability was observed for most of the traits studied. Among all the thirteen traits studied, average fruit weight showed maximum range. Highest phenotypic and genotypic coefficient of variation (PCV and GCV) was observed for fruit yield plant $^{-1}$ (52.27 and 51.71) followed by average fruit weight (45.44 and 44.09) and fruitsplant $^{-1}$ (32.61 and 32.08). Rani and Anitha (2011), Manna and Paul (2012), Patel et al., (2013) and Reddy et al., (2013) also reported similar reports of higher PCV and GCV for fruits per plant, average fruit weight and fruit yield per plant. The lowest value for PCV and GCV was shown by days to $50 \%$ flowering (8.50 and 8.00). Environmental influence was very meagre on expression of these characters as it was evident by narrow gap between genotypic and phenotypic coefficient of variation. Selection among the 
genotypes showing higher values of PCV and GCV will be beneficial for improvement of the trait on account to the variation present for the trait between the genotypes. In general, the estimates of broad sense heritability revealed highest value for fruit yield per plant (97.80) followed by number of fruits plant ${ }^{-1}$ (96.80) and average fruit weight (94.10) where similar reports were made by Bai and Devi (1991), Kumari and Subramanian (1994) and Nwosu et al., (2014). Estimates of genetic advance are more useful in selection than the heritability.

Average fruit weight followed by fruits plant ${ }^{-1}$ and plant height exhibited high heritability coupled with high genetic advance indicating that these characters are governed by additive gene effect. Pujari et al., (1995) also reported high estimates of heritability coupled with high genetic advance for number of fruits plant $^{-1}$ and average fruit weight suggesting that additive gene action would be responsible and selection for these traits could be used developing high yielding varieties. It may also be concluded that selection on the basis of these traits will be more useful for the improvement and towards attaining higher yield. Low genetic advance and heritability for pericarp thickness and primary branches indicates that these traits are chiefly controlled by non-additive gene action.

In the findings of Brar et al., (2000), the number of fruit plant ${ }^{-1}$, average fruit weight and total yield plant ${ }^{-1}$ had low or moderate estimates of phenotypic and genotypic coefficients of variation, heritability and genetic advance which were in contrast to the present investigation.

A thorough knowledge regarding the amount of genetic variability, heritability and genetic advance existing for various characters is essential for initiating the crop improvement programme for development of new varieties.

\section{References}

Bai, N., Devi, D.S. Studies on genetic parameters in tomato hybrids. Orissa J.Agric. Res. 4(1/2): 27-29(1991).

Basavaraj, N.S., Hosamani, R.M., Patil, B.C.: Genetic variability in tomato (Solanum lycopersicon [Mill.] Wettsd.). Karnataka J. Agri. Sci. 23(3): 536537(2010).

Bhandari, H.R., Srivastava, K., Reddy G.E.: Genetic variability, Heritability and Genetic Advance for Yield Traits in Tomato (Solanum lycopersicum L.). Int. J. Current Microbiol. And Appl. Sci. 6(7): 4131-4138.

Bose, T.K., Bose, J., Kabir, T.K., Maity, V.A., Parthasarathy and Som, M.G.: Veg. crops. Bhumani Mitra pub., Kolkata, India (2002).

Brar, G.S., Singh, S., Cheema, D.S., Dhariwal, M.S.: Studies on variability, heritability, genetic advance for yield and components characters in tomato (Lycopersicon esculentum Mill.). J. Res., Punjab Agril. Uni. 37(3/4): 190193(2000).

Dar, R.A., Sharma, J.P. Genetic variability studies of yield and quality traits. Int. $J$. Genet. Pl. Breeding. 5(2): 168174(2011).

FAOSTAT (2013).Food and Agriculture Organization of United Nations. Website: http://www.fao.org/

Kaushik, S. K., Tomar, D. S., Dixit, A. K.: Genetics of fruit yield and it's contributing characters in tomato (Solanum lycopersicum L.). J. Agric. Biotech. Sustainable Devlop. 3(10): 209-213(2011).

Kumari, A.V., Subramanian, M.: Genetic variability in tomato. Madras Agric. J. 8: 657-653(1994).

Manna, M., Paul, A.: Studies on genetic variability and characters association of 
fruit quality parameters in tomato. HortiFlora Res. Spectrum. 1(2): 110116 (2012).

Nwosu D.J., Onakoya O.A., Okere A.U., Babatunde A.O. and Popoola A.F. Genetic Variability and Correlations in Rainfed Tomato (Solanum spps.) Accessions in Ibadan, Nigeria. Greener J Ag. Sci. 4 (5): 211-219(2014).

Patel, S.A., Kshirsagar, D.B., Attar, A.V. and Bhalekar, M.N.: Study on genetic variability, heritability and genetic advance in tomato. Internat. J. Plant Sci., 8 (1): 45-47(2013).

Pujari, C.V., Wagh, R.S., Kale, P.N.: Genetic variability and heritability in tomato. $J$. Maharashtra Agril. Univ. 20(1): 1517(1995).
Rani, K. R., Anitha, V.: Studies on variability, heritability and genetic advance in tomato (Lycopersicon esculentum Mill.). Int.J. Bio-resourse Stress Managment. 2(4): 382-385(2011).

Reddy, B. R., Reddy D. S, Reddaiah K., Sunil N.: Studies on genetic variability, heritability and genetic advance for yield and quality traits in Tomato (Solanum lycopersicum L.). Int.J.Curr.Microbiol.App.Sci (2013) 2(9): 238-244 (2013).

Singh, H., Cheema, D.S. Studies on genetic variability and heritability for quality traits of tomato (Lycopersicon esculentum Mill.) under heat stress conditions. J. Applied Hort. 7(1): 5557(2005).

\section{How to cite this article:}

Bandan Thapa, K. Srivastava and Hemraj Bhandari. 2018. Assessment Studies on Genetic Variability Traits in Different Lines of Tomato (Solanum lycopersicum L.). Int.J.Curr.Microbiol.App.Sci. 7(09): 824-829. doi: https://doi.org/10.20546/ijcmas.2018.709.098 